\title{
Verification of Cau River biochemical water quality forecasted from local governments' socioeconomic projections in Bac Kan and Thai Nguyen provinces, Vietnam Vérification des prédictions de la qualité biochimique de l'eau de la rivière Cau selon les projections socioéconomiques de développement des provinces de Bac Kan et Thai Nguyen au Vietnam
}

\author{
Pham Thi Thu Ha, Jean-Pierre Villeneuve, Sophie Duchesne, Ha Ngoc Hien et \\ Duong Ngoc Bach
}

Volume 31, numéro 3, 2018

Received 10 February 2017, accepted 17 November 2017

URI : https://id.erudit.org/iderudit/1054309ar

DOI : https://doi.org/10.7202/1054309ar

\section{Aller au sommaire du numéro}

\section{Éditeur(s)}

Université du Québec - INRS-Eau, Terre et Environnement (INRS-ETE)

\section{ISSN}

1718-8598 (numérique)

Découvrir la revue

Citer cet article

Ha, P. T., Villeneuve, J.-P., Duchesne, S., Hien, H. \& Bach, D. (2018). Verification of Cau River biochemical water quality forecasted from local governments' socioeconomic projections in Bac Kan and Thai Nguyen provinces, Vietnam. Revue des sciences de l'eau / Journal of Water Science, 31(3), 315-325.

https://doi.org/10.7202/1054309ar

\section{Résumé de l'article}

Cette étude compare les concentrations en $\mathrm{DBO}_{5}$ (demande biochimique en oxygène après cinq jours) mesurées en 2015 et celles prédites pour la rivière Cau avec l'outil GIBSI selon différents scénarios d'évolution du territoire prévus par les autorités. L’objectif est d'expliquer les différences observées. Les résultats montrent qu'en général les concentrations mesurées en $\mathrm{DBO}_{5}$ sont plus faibles que la médiane des valeurs prédites pour l'année 2015 selon les scénarios et qu'elles respectent le critère de qualité de l'eau de surface QCVN 08-MT:2015/BTNMT. Les différences entre les concentrations observées et prédites s'expliquent principalement par le fait que la croissance de la population a été moindre qu'initialement prévu par les autorités dans la ville de Bac Kan. En effet, la population recensée en 2015 dans cette ville était respectivement de $26,19 \%, 28,04 \%$ et 29,08 \% inférieure à celle prévue selon les scénarios de croissance faible (S1), moyenne (S2) et élevée (S3) de la population. Également, la mise en opération d'une station de traitement des eaux usées à Cho Moi, qui n’avait pas été prise en compte dans les scénarios analysés, est un autre facteur ayant entraîné une meilleure qualité de l'eau que celle prédite par les scénarios. Les résultats obtenus montrent que les futurs scénarios de développement devront être mieux élaborés en matière de croissance démographique et mieux tenir compte des prévisions d'investissement pour le traitement des eaux usées, afin d'améliorer les prédictions de qualité de l'eau en rivière. 


\section{VERIFICATION OF CAU RIVER BIOCHEMICAL WATER QUALITY FORECASTED FROM LOCAL GOVERNMENTS' SOCIOECONOMIC PROJECTIONS IN BAC KAN AND THAI NGUYEN PROVINCES, VIETNAM}

Vérification des prédictions de la qualité biocbimique de l'eau de la rivière Cau selon les projections socioéconomiques de développement des provinces de Bac Kan et Thai Nguyen au Vietnam

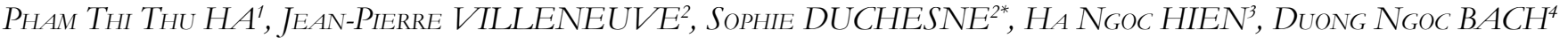

${ }^{1}$ Faculty of Environmental Sciences, VNU University of Science, 334 Nguyen Trai Street, Thanh Xuan District, Hanoi, Vietnam

${ }^{2}$ Centre Eau Terre Environnement, Institut national de la recherche scientifique (INRS), 490 de la Couronne, Québec (Quebec) G1K 9A9, Canada

${ }^{3}$ Vietnam Academy of Science and Technology, Institute of Environmental Technology, 18 Hoang Quoc Viet Street, Cau Giay District, Hanoi, Vietnam

${ }^{4}$ Research Center for Environmental Monitoring and Modeling, VNU University of Science, 334 Nguyen Trai Street, Thanh Xuan District, Hanoi, Vietnam

Received 10 February 2017, accepted 17 November 2017

\section{ABSTRACT}

In this study, we made a verification of water quality between forecasted and monitoring data in 2015 to find out the differences for Cau River water quality, $\mathrm{BOD}_{5}$ concentration (5-day Biochemical Oxygen Demand). Then, an analysis on main development factors which may cause these differences was made. The results showed that in general, $\mathrm{BOD}_{5}$ monitoring concentrations are lower than forecasted median results and meet the standard QCVN 08-MT:2015/BTNMT for surface water quality, while the forecasted concentrations in some periods are over the standard. Local government' control of population growth in Bac Kan City is considered as one of the major reasons to make Cau River water quality better than forecasted. The statistic population data of Bac Kan City in 2015 is lower than the forecasted population: $26.19 \%$ lower than the forecasted in the low population growth scenario (S1), 28.04\% in the medium population growth scenario (S2), and $29.8 \%$ in the high population growth scenario (S3). Besides, the operation of domestic wastewater treatment plant in Cho Moi Town, which was not considered in developing and assessing the impacts of population scenarios on water quality, is also considered as one of the reasons why the Cau River monitoring water quality $\left(\mathrm{BOD}_{5}\right.$ concentration) is better than forecasted. This verification result is important and 
useful for increasing the quality of scenario development and water quality forecast in the future.

Key words: water quality, verification, GIBSI, Cau River basin, scenarios.

\section{RÉSUMÉ}

Cette étude compare les concentrations en $\mathrm{DBO}_{5}$ (demande biochimique en oxygène après cinq jours) mesurées en 2015 et celles prédites pour la rivière Cau avec l'outil GIBSI selon différents scénarios d'évolution du territoire prévus par les autorités. L'objectif est d'expliquer les différences observées. Les résultats montrent qu'en général les concentrations mesurées en $\mathrm{DBO}_{5}$ sont plus faibles que la médiane des valeurs prédites pour l'année 2015 selon les scénarios et qu'elles respectent le critère de qualité de l'eau de surface QCVN 08-MT:2015/ BTNMT. Les différences entre les concentrations observées et prédites s'expliquent principalement par le fait que la croissance de la population a été moindre qu'initialement prévu par les autorités dans la ville de Bac Kan. En effet, la population recensée en 2015 dans cette ville était respectivement de $26,19 \%, 28,04 \%$ et 29,08 \% inférieure à celle prévue selon les scénarios de croissance faible (S1), moyenne (S2) et élevée (S3) de la population. Également, la mise en opération d'une station de traitement des eaux usées à Cho Moi, qui n'avait pas été prise en compte dans les scénarios analysés, est un autre facteur ayant entraîné une meilleure qualité de l'eau que celle prédite par les scénarios. Les résultats obtenus montrent que les futurs scénarios de développement devront être mieux élaborés en matière de croissance démographique et mieux tenir compte des prévisions d'investissement pour le traitement des eaux usées, afin d'améliorer les prédictions de qualité de l'eau en rivière.

\section{Mots-clés : qualité de l'eau, vérification, GIBSI, rivière Cau, scénarios.}

\section{INTRODUCTION}

Cau River is a river in the North of Vietnam. The natural area of the river basin is $6030 \mathrm{~km}^{2}$, representing $2 \%$ of the total country area (MONRE, 2006). In this river basin, population and industrial growths are considered as major concerns of local authorities due to their impacts on degradation of water quality. Therefore, water quality improvement for Cau River basin is one of the priorities of the Vietnamese government (PHAM, 2013).
Several socio-economic development scenarios for Cau River basin were created in 2010 (PHAM, 2013; PHAM et al., 2016), in which there were three scenarios of population ( $S 1$, S2, S3) and three industrial scenarios (S4, S5, S6). Population and industrial factors were considered as major causes for the degradation of water quality in the Cau River basin. These scenarios were built mainly based on local projections for population and industrial growths in two future years of 2015 and 2020, and then being assessed to know their impacts on future water quality of Cau River by using GIBSI computer tool. The scenarios and their impact on water quality are described in details in PHAM (2013) and PHAM et al. (2016).

In this research, the authors carried out a verification of the forecasted water quality results for Cau River. Monitoring water quality data of Cau River at Thac Rieng and Gia Bay stations were collected during five periods in 2015 and compared with the forecasted data. This verification is very important to understand the forecast quality and developed scenarios' quality.

\section{STUDY AREA}

The study area in this research is the upstream of Cau River basin in Bac Kan and Thai Nguyen provinces (Figure 1). Bac Kan province includes eight administrative units, among which four units are related to the Cau River basin. Thai Nguyen province has nine units, whose all units are related to the Cau River basin. The Cau River, whose total length is $288 \mathrm{~km}$, is located in the North-East of Vietnam. It is one of the largest rivers of the Thai Binh River system.

This study focuses on verification of Cau River water quality in two river reaches at Thac Rieng and Gia Bay monitoring stations (Figure 2).

\section{METHODOLOGY}

\subsection{Method of scenario development}

Scenario development for integrated watershed management is based on probable changes in the future of socioeconomic and environmental factors such as population, industry, agriculture, land use conversion, domestic wastewater, and climate change. System analysis of local governments' projections will help to define the probable changes in future. Due to the scarcity of available data for system analysis in several countries, especially in developing countries such as Vietnam, realistic assumptions 


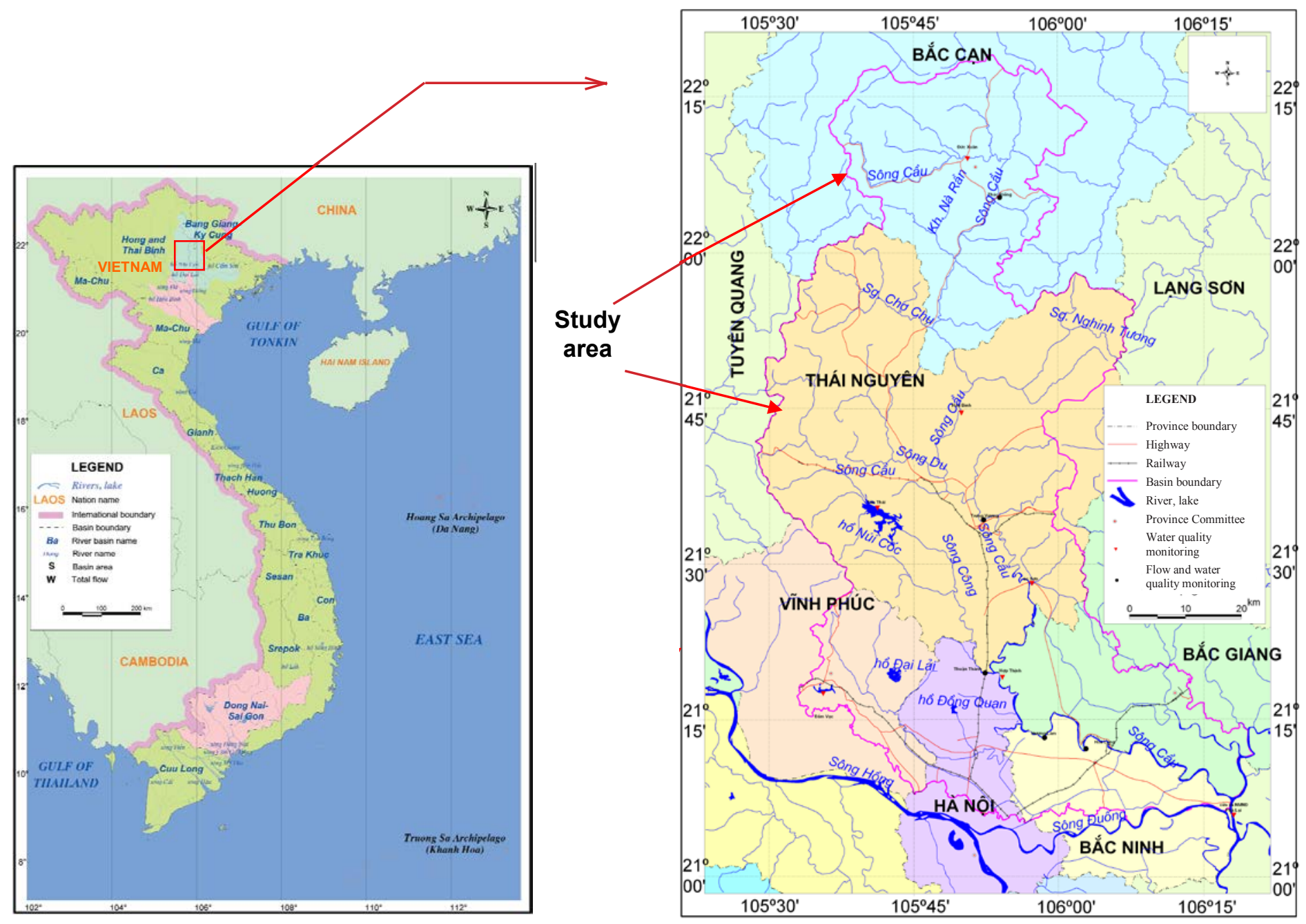

Figure 1. Map of Cau River basin in Vietnam and the study area which corresponds to the parts of the Cau River basin located in Bac Kan and Thai Nguyen provinces (PHAM et al., 2016).

Carte du bassin versant de la rivière Cau au Vietnam et de la zone d'étude qui correspond à la partie du bassin versant qui est située dans les provinces de Bac Kan et de Thai Nguyen (PHAM et al., 2016).

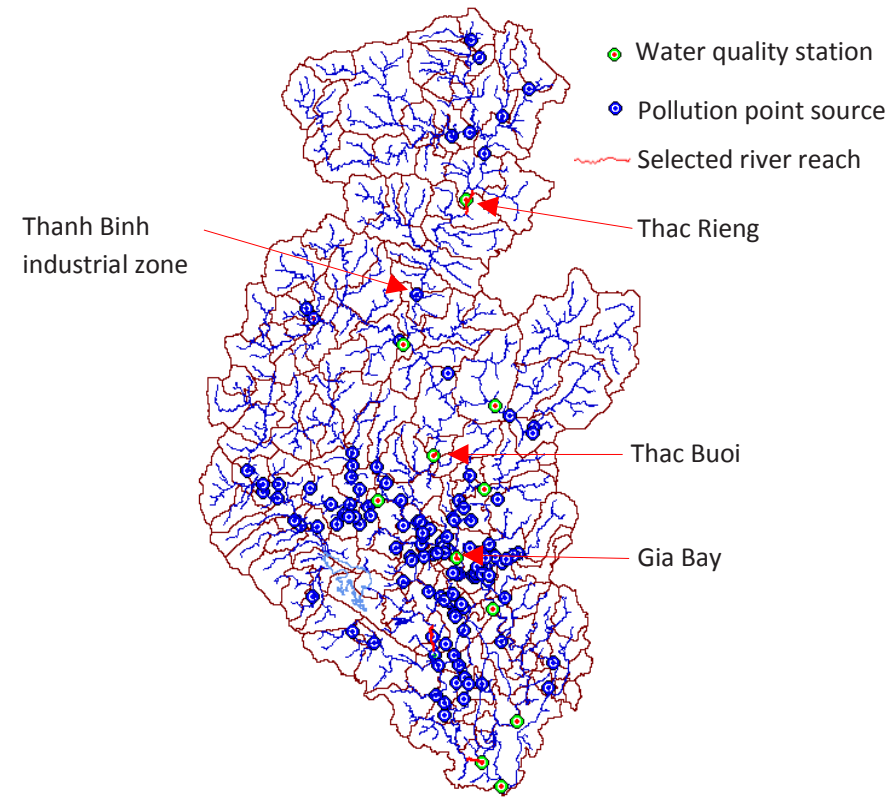

Figure 2. Location of the three selected river reaches and point pollution sources (PHAM et al., 2016).

Localisation des trois tronçons de rivière sélectionnés et des sources ponctuelles de pollution (PHAM et al., 2016). 
are needed for scenario development. For example, assumption of capacity of domestic wastewater treatment plants, or increase of wastewater discharge of current industrial factories. Finally, scenarios are created by different combinations of the probable changes and assumptions for the above socioeconomic and environmental factors (Figure 3). For example, a scenario, which is created to assess the impact of domestic wastewater on water quality combines the factors of projections for population growth and projection and assumptions for domestic wastewater treatment plants' capacities. The impacts of the developed scenarios on river water quality are assessed by using water quality simulation models.

\subsection{Method of water quality forecast}

There are several river basin integrated management simulation tools which can be used to assess the impacts of socioeconomic development scenarios on stream flow and river water quality such as SWAT (NEITSCH et al., 2009) and GIBSI (VILLENEUVE et al., 1998; ROUSSEAU et al., 2000). In this research, GIBSI was used to assess the impacts of developed socioeconomic scenarios on Cau River water quality. GIBSI is a computer tool which includes four main components (Figure 4) (QUILBÉ and ROUSSEAU, 2007):

1. Database management system with a geographical information system (GIS), including spatial data such as gauge stations locations and attribute data such as database of soil types which are required for developing scenarios and running simulation.

2. Scenario management component that helps developing various watershed management scenarios.

3. Four simulation models:

- HYDROTEL, a distributed physically-based hydrological model (FORTIN et al., 1995);

- MODEROSS (DUCHEMIN, 2000) and ROTO (ARNOLD et al., 1998), used for soil erosion and sediment transport in rivers;

- PoPES, a pollutant transport model (LASBLEIS et al., 2008);

- QUAL2E, a river water quality model (BROWN and BARNWELL, 1987).

All these models in GIBSI should be calibrated for the studied watershed before assessing the impacts of developed scenarios on river water quality.

4. Post-processing tools that are used to analyze and visualize simulation results.

\subsection{Method of verification}

This method includes the following steps: 1) collecting monitoring data of water quality and current socioeconomic development in 2015; 2) data treatment:
- Comparing the forecasted and current data of Cau River water quality in 2015 in two monitoring stations of Thac Rieng and Gia Bay;

- Comparing and analyzing the current socio-economic development in 2015 and local governments' former projections to find out the reasons of the differences between the forecasted and current water quality of Cau River.

\section{RESULTS AND DISCUSSION}

\subsection{Results of water quality forecast}

In this study, 14 scenarios were built in order to assess the impacts of seven factors: population, domestic wastewater, industry, livestock, agricultural fertilizer, land use conversion, climate change. After assessing the impacts of these scenarios on Cau River water quality by using GIBSI, it was found that two factors which have significant impacts on water quality of Cau River in the study area are population and industry (PHAM, 2013; PHAM et al., 2016). The six developed scenarios to assess the impacts of these two main factors are called scenarios from $S 1$ to S6, in which S1, S2, and S3 are three scenarios for assessing the impacts of population and domestic wastewater, and S4, S5, and S6 are scenarios for industry.

Scenarios S1, S2, and S3 are the combination of the low, medium, and high future population growths and the low, medium, and high capacities of domestic wastewater treatment plant, respectively.

Scenarios S4, S5, and S6 are the combination of the local governments' projection for the 14 new industrial zones and the different future industrial growths of current factories (keep current discharge, increase 5\% in 2015 and $10 \%$ in 2020 , increase $10 \%$ in 2015 and $20 \%$ in 2020 , respectively). In these three scenarios, we assumed that all industrial factors meet the Vietnamese standard for industrial wastewater.

Results of Cau River water quality forecast for the six above scenarios in 2015 and 2020 is compared with the state in 2009 in figures 5 and 6 . In these figures, concentrations of $\mathrm{BOD}_{5}$ are displayed by boxplot for each scenario in the future and for the reference situation. Each boxplot was represented with the 365 simulated values which correspond to 365 days in one year. The green lines in these figures indicate the $\mathrm{BOD}_{5}$ concentrations in the Vietnamese standard for surface water quality; the lower line is the standard value for the purpose of water supply with treatment (A2) $\left(6 \mathrm{mg} \cdot \mathrm{L}^{-1}\right.$ for $\left.\mathrm{BOD}_{5}\right)$ and the upper line is the standard value for the purpose of irrigation and other purposes (B1) $\left(15 \mathrm{mg} \cdot \mathrm{L}^{-1}\right.$ for $\left.\mathrm{BOD}_{5}\right)$. 


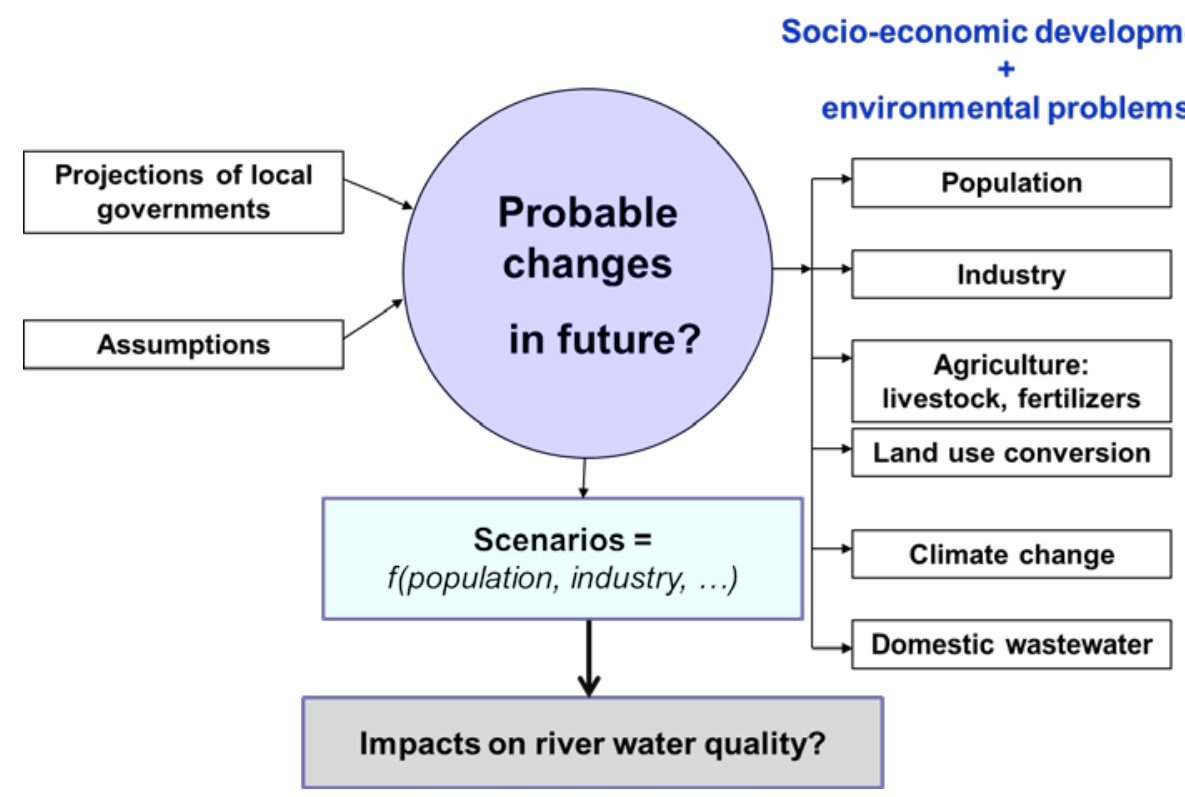

Figure 3. Method of scenario development for integrated watershed management.

Méthode de développement des scénarios pour la gestion intégrée par bassin versant.

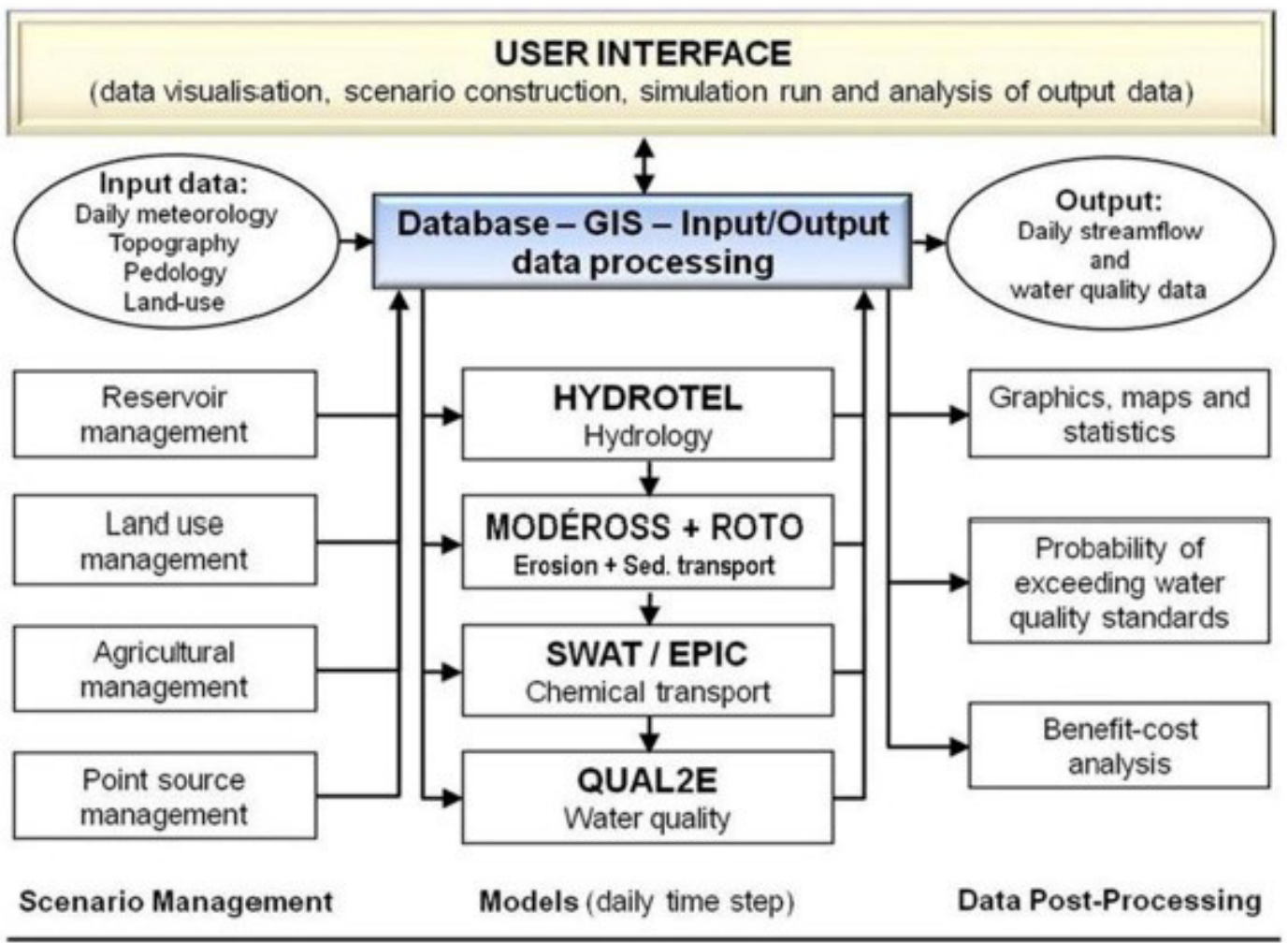

Figure 4. Representation of the GIBSI components (adapted from QUILBÉ and ROUSSEAU, 2007). Description de la structure de GIBSI et de ses composantes (adaptée de QUILBÉ et ROUSSEAU, 2007). 

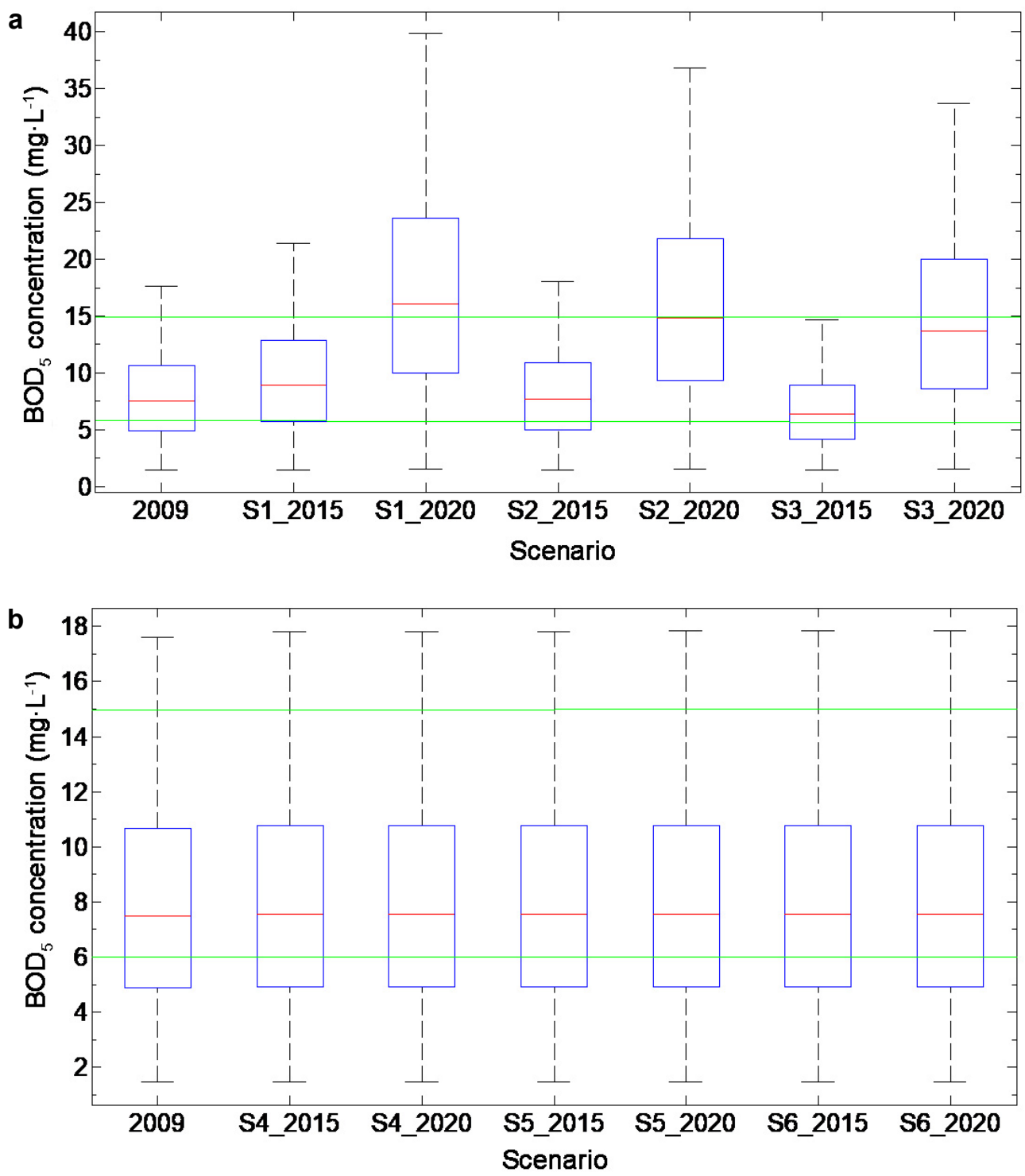

Figure 5. Simulation results of $\mathrm{BOD}_{5}$ concentration in 2015 and 2020 at Thac Rieng for scenarios a) S1, S2, S3, and b) S4, S5, S6, compared with the reference year 2009 (PHAM, 2013). Concentrations en $\mathrm{DBO}_{5}$ simulées en 2015 et 2020 à Thac Rieng pour les scénarios a) S1, S2, S3 et b) S4, S5, S6, comparées avec l'année de référence 2009 (PHAM, 2013).

The simulation results in two river reaches, namely at Thac Rieng and Gia Bay monitoring stations, in Cau River showed that:

- At Thac Rieng: fast future population growth in Bac Kan has significant impacts on the increase of $\mathrm{BOD}_{5}$ concentrations in the future. The reason why population in Bac Kan is expected to grow fast is that Bac Kan Town was planned to become a city in 2015. Figure 5a shows that even if Bac Kan town installs a domestic wastewater treatment plant with a capacity of 10000 people in 2015 , as in the local government projection, the median value of $\mathrm{BOD}_{5}$ concentration is higher than the concentration in the reference state (Figure 5a, S1_2015). However, if the capacity of domestic wastewater treatment plant in Bac Kan Town is increased to 20000 people (S2_2015) and 30000 people (S3_2015), the water quality will be improved. Figure $5 \mathrm{~b}$ shows that this river reach does not seem to be affected by industrial activities. The $\mathrm{BOD}_{5}$ concentrations in scenarios S4, S5, and S6 in future years are the same as in the reference state. This can be explained by the fact that in the upstream area of this river reach, there is no new future industrial zone, and the wastewater of all current factories is supposed to meet the standard for industrial wastewater.

- At Gia Bay: The river reach at Gia Bay station is the outlet of the studied region of Cau River basin. From the upstream of Cau River to this outlet, there are two domestic wastewater treatment plants which will were planned to be installed in 2015, in Bac Kan Town and in Thai Nguyen City. Figure 6a shows that $\mathrm{BOD}_{5}$ concentrations in all three scenarios $\mathrm{S} 1$, 

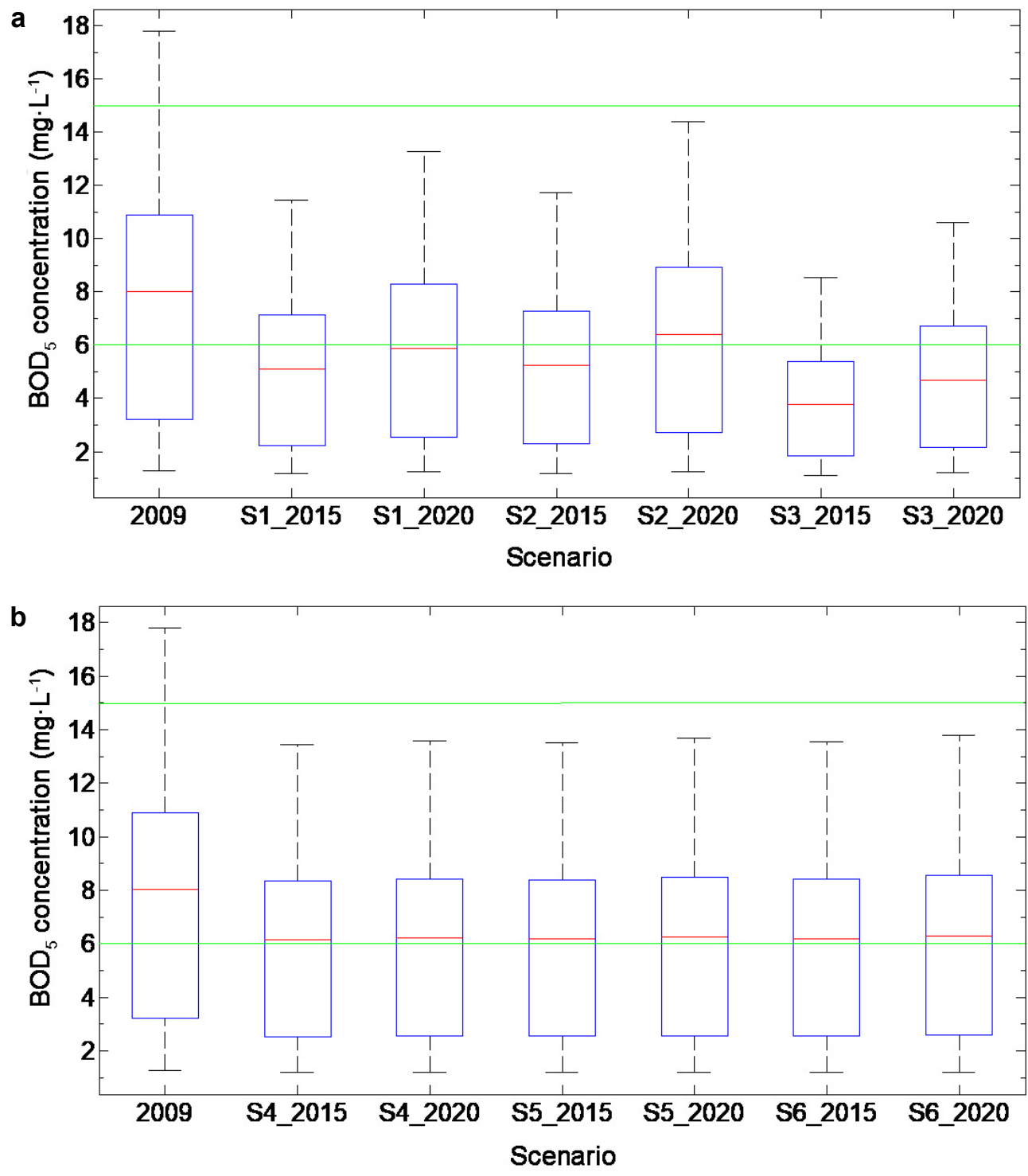

Figure 6. Simulation results of $\mathrm{BOD}_{5}$ concentration in 2015 and 2020 at Gia Bay for scenarios a) S1, S2, S3, and b) S4, S5, S6, compared with the reference year 2009 (PHAM, 2013; PHAM et al., 2016).

Concentrations en $\mathrm{DBO}_{5}$ simulées en 2015 et 2020 à Gia Bay pour les scénarios a) S1, S2, S3 et b) S4, S5, S6, comparées avec l'année de référence 2009 (PHAM, 2013; PHAM et al., 2016).

S2 and S3 in both future years decrease compared with the reference state. In general, the water quality is improved if these two domestic wastewater treatment plants are installed and operated, even with the smallest capacities in scenario S1 (capacity of 10000 people for treatment plant in Bac Kan Town and capacity of 100000 people for treatment plant in Thai Nguyen City). For three scenarios S4, S5 and S6 (impacts of industry), figure 6b shows that $\mathrm{BOD}_{5}$ concentrations in both future years decrease compared with the reference state. This is due to the fact that in the future, all industries are supposed to meet the standards for industrial wastewater.

\subsection{Results of water quality verification}

The monitoring data for verification of Cau River water quality, collected from Center for Environmental Monitoring (CEM), Vietnam Environment Administration (VEA), are from five monitoring periods in 2015, which are:

- Period 1:5-13 May 2015;

- Period 2: 15-22 July 2015;

- Period 3: 10-16 September 2015;

- Period 4: 9-15 October 2015;

- Period 5: 2-9 December 2015. 
These are the annual regular monitored values for Cau River. Only one sample was collected for each monitoring point along Cau River during each monitoring period. Therefore, there was only one value of $\mathrm{BOD}_{5}$ concentration for each of five monitoring periods at each river reach.

The monitored data of Cau River water quality at Thac Rieng and Gia Bay in these five periods of time and the median values of the forecasted data series in 2015 for scenarios S1 to $S 6$ were used for comparison and verification. Results of Cau River water quality verification between monitoring data and the forecasted data of the six scenarios of population and industry, compared with the Vietnamese standards of surface water quality QCVN 08-MT:2015/BTNMT (A2 for the purpose of water supply with treatment and B1 for the irrigation purpose), are shown in figures 7 and 8 .

The verification results in above figures show that, in general, $\mathrm{BOD}_{5}$ monitoring concentrations are lower than the forecasted results in all of five periods of time in 2015. The $\mathrm{BOD}_{5}$ monitoring concentrations in all of five periods in 2015 meet the standard QCVN 08-MT:2015/BTNMT of both purposes $\mathrm{A} 2$ and $\mathrm{B} 1$, while the forecasted median values in some cases are over the standard for the purpose of water supply with treatment (A2), especially at Thac Rieng (Figures 7a and $7 b)$. The differences between the forecasted median values in S4, S5 and S6 were not significant, which were $7.56 \mathrm{mg} \cdot \mathrm{L}^{-1}$ in $\mathrm{S} 4,7.56 \mathrm{mg} \cdot \mathrm{L}^{-1}$ in $\mathrm{S} 5,7.57 \mathrm{mg} \cdot \mathrm{L}^{-1}$ in $\mathrm{S} 6$ at Thac Rieng, and $6.16 \mathrm{mg} \cdot \mathrm{L}^{-1}$ in $\mathrm{S} 4,6.18 \mathrm{mg} \cdot \mathrm{L}^{-1}$ in $\mathrm{S} 5,6.20 \mathrm{mg} \cdot \mathrm{L}^{-1}$ in $\mathrm{S} 6$ at Gia Bay, therefore there was an overlap of three lines for S4, S5 and $\mathrm{S} 6$ in figures $7 \mathrm{~b}$ and $8 \mathrm{~b}$. These verification results show that the monitoring results in reality of Cau River water quality $\left(\mathrm{BOD}_{5}\right.$ concentrations) show a better water quality than the forecasted results.

\subsection{Discussion}

The verification results show that the local governments in Bac Kan and Thai Nguyen provinces well controlled the Cau River biochemical water quality in 2015. In order to know the reasons of this good control of water quality, we implemented a review of the projected growths in the six scenarios and made a comparison with the population and industrial growths in reality in these two provinces. This review showed several differences which may be the reasons of good control of Cau River water quality in 2015. These differences are discussed below.

\subsubsection{Population and domestic wastewater treatment plants}

In the three developed scenarios for population, the population in Bac Kan Town was forecasted to grow fast with three level of growth: low in scenario S1, medium in S2, and high in S3 because the local government wished Bac Kan
Town to become a city in 2015. This wish came true, Bac Kan Town became Bac Kan City in March, 2015. However, the actual population data of Bac Kan City in 2015 (BAC KAN STATISTICS OFFICE, 2016) was lower than the forecasted population in all three scenarios for population: $26.2 \%$ lower than forecasted in scenario S1, 28.0\% in S2, and 29.8\% in S3. This may be one of the reasons for Cau River water quality to be better than forecasted, due to less pressure from the impact of fast population growth in Bac Kan Town.

On the contrary, the population data of Thai Nguyen City in 2015 (THAI NGUYEN STATISTICS OFFICE, 2016) was higher than forecasted. However, the difference between real and forecasted population data in 2015 in Thai Nguyen City is not important, only $11.4 \%$ in the low population growth scenario $\mathrm{S} 1,7.3 \%$ in the medium population growth scenario S2, and $5.1 \%$ in the high population growth scenario S3, as compared with the forecasted population. The differences between the real and forecasted population in Bac Kan and Thai Nguyen cities are indicated in figure 9.

Regarding the domestic wastewater treatment plants, it was projected by the local governments, in the three population scenarios S1, S2, and S3, that there would be two domestic wastewater treatment plants in Bac Kan Town and Thai Nguyen City in 2015. These projections went into practice, since these two domestic wastewater treatment plants are now in operation with capacities as local projections: $3000 \mathrm{~m}^{3} \cdot \mathrm{d}^{-1}$ (or for around 10000 connected people) in Bac Kan City and $21000 \mathrm{~m}^{3} \cdot \mathrm{d}^{-1}$ (or for 100000 connected people) in Thai Nguyen City. Besides, domestic wastewater treatment plant in Cho Moi Town, which belongs to Cho Moi district, Bac Kan province, was constructed and is in operation with a capacity of $800 \mathrm{~m}^{3} \cdot \mathrm{d}^{-1}$. This treatment plant in Cho Moi Town was not considered in developing and assessing the impacts of population scenarios S1, S2, S3. This is also considered as one of the reasons why the Cau River monitored water quality $\left(\mathrm{BOD}_{5}\right.$ concentration) is better than forecasted.

\subsubsection{Industry}

To develop industrial scenarios S4, S5, and S6, it was assumed that wastewater from all industrial factories meets the Vietnamese standards for industrial wastewater, because all industries must meet these standards according to Vietnamese environmental protection law. The monitoring results show that the Cau River water quality $\left(\mathrm{BOD}_{5}\right.$ concentration) in 2015 was good, and below the Vietnamese standard for surface water quality, even for the purpose of water supply with treatment (A2). This indicates that the industrial development in Bac Kan and Thai Nguyen in recent years did not increased much, and/or that the local governments have controlled well the quality of industrial wastewater from factories in the study area. 
a

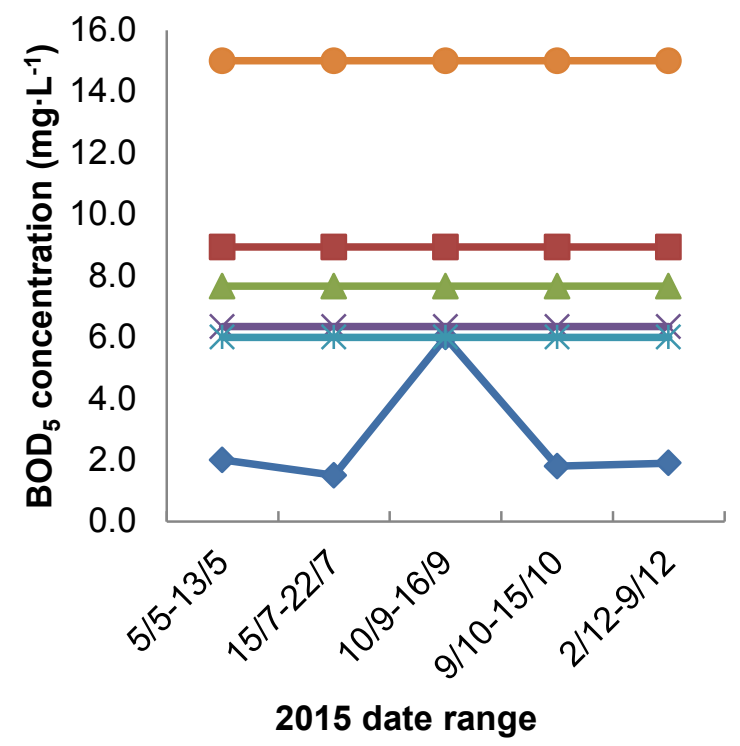

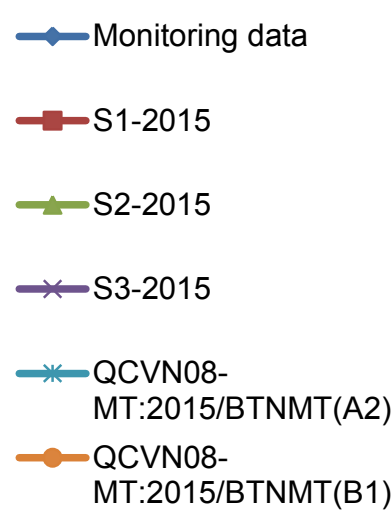

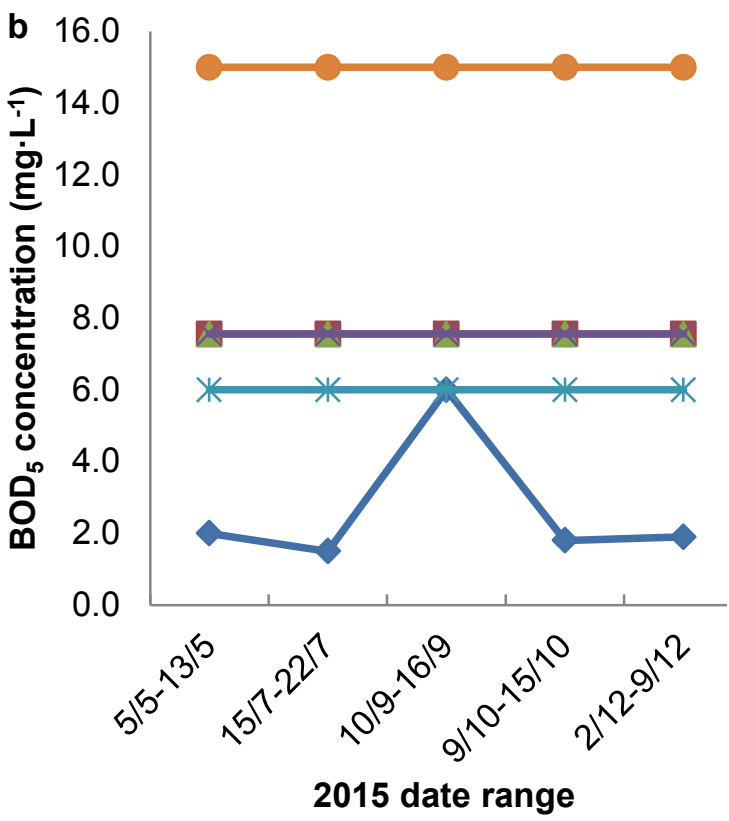

Figure 7. Verification of $\mathrm{BOD}_{5}$ concentration in 2015 at Thac Rieng for scenarios a) S1, S2, S3, and b) S4, S5, S6.

Vérification des concentrations de $\mathrm{DBO}_{5}$ en 2015 à Thac Rieng pour les scénarios a) S1, S2, S3 et b) S4, S5, S6.

a

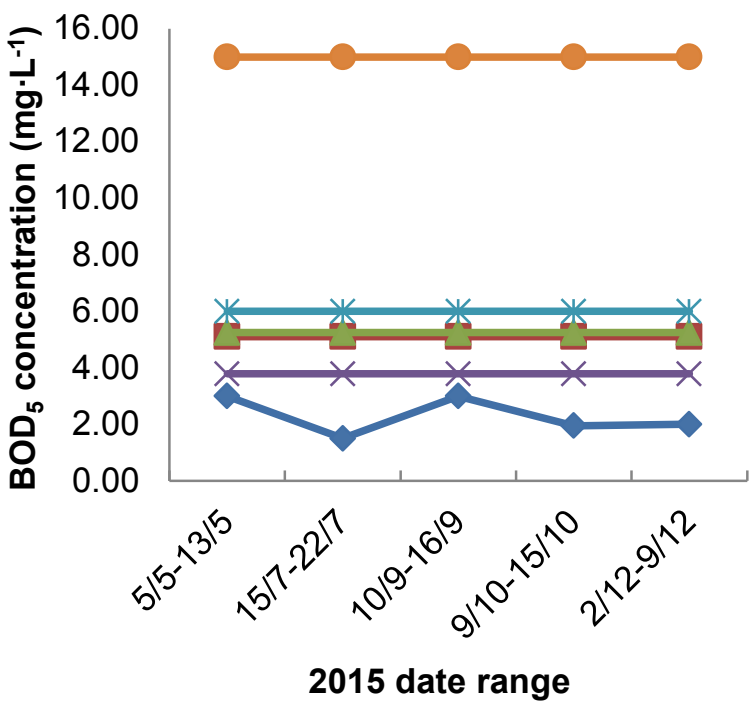

b
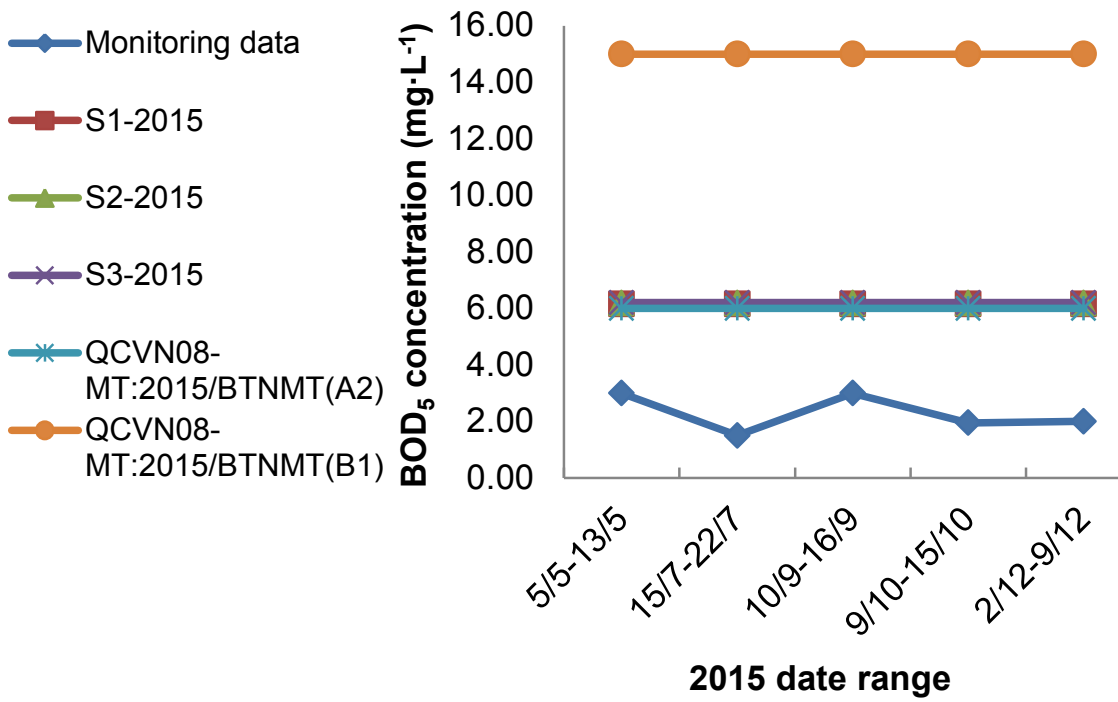

Figure 8. Verification of $\mathrm{BOD}_{5}$ concentration in 2015 at Gia Bay for scenarios a) S1, S2, S3, and b) S4, S5, S6.

Vérification des concentrations de $\mathrm{DBO}_{5}$ en 2015 à Gia Bay pour les scénarios a) S1, S2, S3 et b) S4, S5, S6.

\section{CONCLUSION}

The verification result showed that, in general, the quality of socio-economic scenario development based on local projections and forecasted water quality results, which were simulated by GIBSI for Cau River, is relatively accurate. The fact that the monitored water quality is better than the forecasted water quality may be due to the population being lower than forecasted in Bac Kan City. Besides, another reason which may lead to a water quality better than forecasted in Cau River is the operation of a domestic wastewater treatment plant in Cho Moi Town, which was not taken into consideration in the developed scenarios. This verification result can provide guidance for increasing quality of scenario development, useful for water quality forecast. 


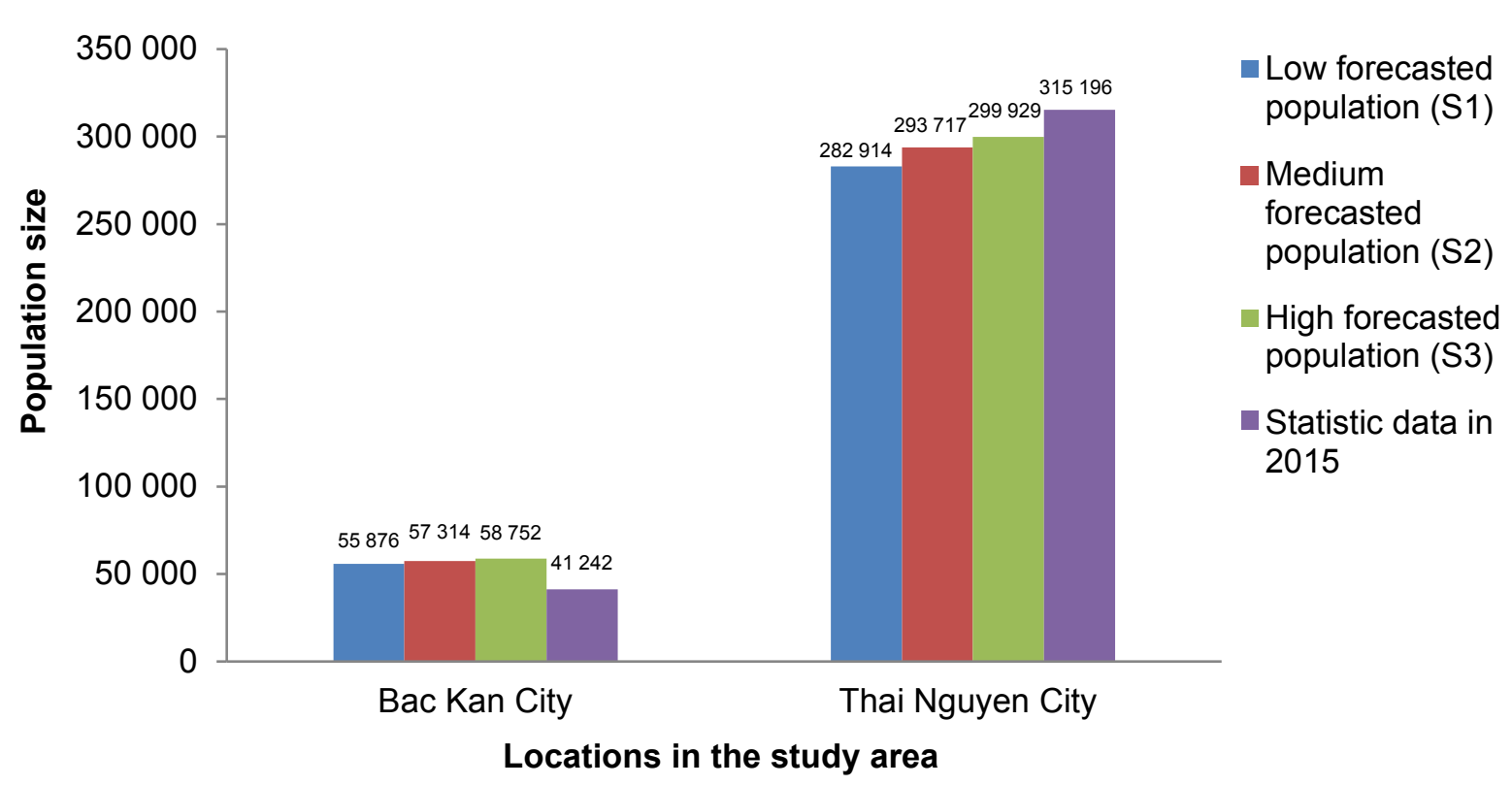

Figure 9. Verification of population in 2015 in Bac Kan and Thai Nguyen cities. Vérification de la population en 2015 dans les villes de Bac Kan et Thai Nguyen.

\section{ACKNOWLEDGEMENT}

The authors would like to thank CIDA for funding of the co-operation project between Institut national de la recherche scientifique (INRS) and Vietnam Academy of Science and Technology (VAST) on "Cau River basin integrated management".

\section{REFERENCES}

ARNOLD J.G, R. SRININASAN, R.S. MUTTIAH and J.R. WILLIAMS (1998). Large area hydrologic modeling and assessment part I: Model development. J. Am. Water Res. Assoc., 34, 73-89.

BAC KAN STATISTICS OFFICE (2016). Bac Kan Statistical Yearbook 2015. Statistical Publishing House, General Statistics Office of Vietnam, Hanoi, Vietnam, 349 p.

BROWN L.C. and T.O. BARNWELL Jr. (1987). The Enhanced stream water quality models QUAL2E and QUAL2E-UNCAS: Documentation and user manual. US Environmental Protection Agency, Athens, GA, USA, $189 \mathrm{p}$.
DUCHEMIN M. (2000). Approche géomatique pour simuler l'érosion hydrique et le transport des sédiments à l'échelle des petits bassins versants agricoles. $\mathrm{PhD}$ thesis, Univ. Québec, INRS, Canada, 317 p.

FORTIN J.P., R. MOUSSA, C. BOCQUILLON and J.P. VILLENEUVE (1995). HYDROTEL, un modèle hydrologique distribué pouvant bénéficier des données fournies par la télédétection et les systèmes d'informations géographiques. J. Water Sci., 8, 97124.

LASBLEIS F., S. SAVARY and A.N. ROUSSEAU (2008). Amélioration et calage du modèle de transport de polluants et pesticides (POPES) et application sur le bassin versant de la rivière Beaurivage. Research report R-1022, INRS, Centre Eau Terre Environnement, Québec (QC), Canada, 91 p.

VIETNAMESE MINISTRY OF NATURAL RESOURCES AND ENVIRONMENT (MONRE) (2006). Environment report of Vietnam: The current state of water environment in 3 river basins of Cau, Nhue - Day and Dong Nai river system. Hanoi, Vietnam, 92 p.

NEITSCH S.L., J.G. Arnodl, J.R. KINIRY and J.R. WILLIAMS (2009). Soil and water assessment tool Theoretical documentation, Version 2009. Grassland, Soil and Water Research Laboratory, Blackland Research Center, Texas Water Resources Institute, Temple, TX, USA, $647 \mathrm{p}$. 
PHAM T.T.H. (2013). Choix des meilleures interventions pour l'amélioration de la qualité de l'eau à l'aide d'un outil informatique de gestion intégrée : cas du bassin versant de la rivière Cau au Vietnam. PhD thesis, Univ. Québec, INRS, Canada, 208 p.

PHAM T.T.H, N. KOKUTSE, S. DUCHESNE, J.P. VILLENEUVE, A. BÉLANGER, N.H. HA, B. TOUMBOU and N.B. DUONG (2016). Assessing and selecting interventions for river water quality improvement within the context of population growth and urbanization: a case study of the Cau River basin in Vietnam. Environ. Dev. Sustain., 19, 1701-1729.

QUILBÉ R. and A.N. ROUSSEAU (2007). GIBSI: an integrated modelling system for watershed management - Sample applications and current developments. Hydrol. Earth Syst. Sci., 11, 1785-1795.
ROUSSEAU A.N., A. MAILHOT, R. TURCOTTE, M. DUCHEMIN, C. BLANCHETTE, M. ROUX, N. ETONG, J. DUPONT and J.P. VILLENEUVE (2000). GIBSI - An integrated modeling system prototype for river basin management. Hydrobiologia, 422/423, 465-475.

THAI NGUYEN STATISTICS OFFICE (2016). Thai Nguyen Statistical Yearbook 2015. Statistical Publishing House, General Statistics Office of Vietnam, Hanoi, Vietnam, $327 \mathrm{p}$.

VILLENEUVE J.P., C. BLANCHETTE, M. DUCHEMIN, J.F. GAGNON, A. MAILHOT, A.N. ROUSSEAU, M. ROUX, J.F. TREMBLAY et R. TURCOTTE (1998). Rapport final du projet GIBSI : gestion de l'eau des bassins versants à l'aide d'un système informatisé - Tome 1. Research report R-462, INRS, Centre Eau Terre Envionnement, Québec (QC), Canada, 371 p. 